\title{
Determining the Brand Loyalty of Health Tourism of Ranong Province, Thailand
}

\author{
Witthaya Mekhum ${ }^{1} \&$ Sakarin Sriupayo ${ }^{1}$ \\ ${ }^{1}$ Suan Sunandha Rajabhat University, Thailand \\ Correspondence: Sakarin Sriupayo, Suan Sunandha Rajabhat University, Bangkok, Thailand. E-mail: \\ sakarin.sr@ssru.ac.th
}

Received: July 17, 2020

Accepted: September 4, 2020

Online Published: September 23, 2020

doi:10.5430/rwe.v11n6p1

URL: https://doi.org/10.5430/rwe.v11n6p1

\begin{abstract}
Objective of this study is to examine the brand loyalty of health tourism. For this purpose, the relationship between brand goodwill $(\mathrm{BG})$, brand experience $(\mathrm{BE})$, brand personality $(\mathrm{BP})$, tourist brand trust and health tourism brand loyalty were examined. A survey was carried out and data were collected from the health tourists. Therefore, 300 questionnaires were distributed among the health tourists in Ranong city of Thailand. Partial Least Square (PLS) was used for data analysis. Results of the study highlighted that; BG, BEand BP have positive effect on brand loyalty. Better BG, BE and BP have the potential to enhance brand loyalty of health tourism. Therefore, increase in BG, brand experience, BP increases the brand loyalty. Finally, the tourist brand trust also has positive effect to enhance brand loyalty. Therefore, health tourism brand loyalty has four determinants; BG, brand experience, BP and tourist brand trust. This study is significant theoretical and practical implication for tourism management practitioners of Ranong city.
\end{abstract}

Keywords: health tourism, BG, brand experience, BP, tourist brand trust

\section{Introduction}

Health tourism is an important part of tourism industry as it has significant importance for various countries. Health tourism has key potential for different countries in terms of revenue generation. This type of tourism has major contribution to boost overall tourism industry. Because it is one of the important sources of revenue generation. Literature also shows the significant importance of health tourism (Jeong, Kim, \& Yu, 2020; Wilkinson, 2020). However, health tourism is varying from country to country based on the services of health sector. Thailand also has significant potential for health tourism. It is one of the good markets of health tourism. Various health facilities in Thailand is the attraction for the people to come from other countries to take health services.

Particularly, the Ranong city of Thailand also has significant potential for tourists. In each year, thousands of tourists visit various places to get health services. Moreover, Ranong is also good market for health tourism. It has the potential to contribute to the health tourism. The importance of Ranong for tourism is also highlighted in the literature (Pranee, Boonying, \& Suchookorn, 2020). Therefore, according to the other studies and according to the current study, Ranong has important role in tourism. It has significant attraction for tourism including health tourism. This city of Thailand also has the good facilities to attract tourist related to the health. Nowadays, health tourism is increasing in Thailand as it is highlighted in Figure 1. It is expected that global health tourism will reach USD 179.6 billion by 2026 in which Thailand has significant contribution. Therefore, it is clear that health tourism has important potential for tourism industry in Thailand.

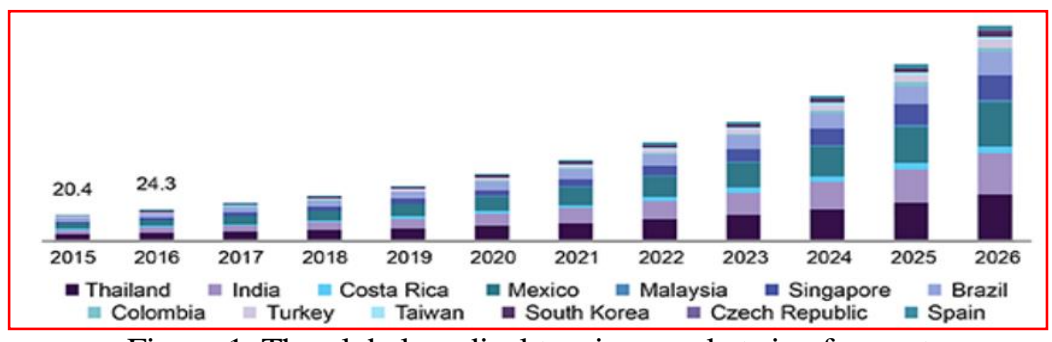

Figure 1. The global medical tourism market size forecast

Source: Www. Grandviewresearch.com 
However, health tourism is facing issues related to the brand loyalty. To develop a good brand loyalty for health tourism is one of the difficult tasks for companies. Because the brand loyalty of health tourism is based on the health services. Better health services create good brand loyalty; however, low health services show negative effect on health tourism. Services provided for health tourism also based on the availability of the health services. In various countries, the health services are not good, that is the reason the brand loyalty creation is not easily. In case of Ranong city, it has the potential to provide good health services, therefore, a good health tourism brand loyalty can be generated. As the health services are significant linked with health tourism (Kashuba, Goncharova, \& Butenko, 2016). Therefore, this study is an attempt to highlight the health tourism brand loyalty in Ranong province, Thailand.

Brand loyalty is one of the importance concept which has different key elements (Foroudi, Jin, Gupta, Foroudi, \& Kitchen, 2018). According to the current study, brand goodwill (BG) is an important element which may effect on the health sector brand loyalty. Better brand image in the minds of tourists help to increase the level of brand loyalty. Along with BG, brand personality (BP) also has significant role in health tourism brand loyalty. It is also highlighted by number of studies that BP is the major element of brand loyalty (Yang, Isa, Ramayah, \& Blanes, 2019). Furthermore, it is also evident that brand experience (BE) has significant contribution to brand loyalty. In health tourism, the tourists having good brand experience, generally more loyal to the brand, however, the tourists having low level of experience, are less loyal to the brand. As it is described by Iglesias, Markovic, and Rialp (2019), that $\mathrm{BE}$ has major role in brand loyalty development. Along with BG, BE and brand loyalty, tourist brand trust also has important role in brand loyalty development. Better trust on brand usually increases the brand loyalty, however, low level of trust decreases the brand loyalty.

Various studies carried out in the field of health tourism (de Almeida \& Ribeiro, 2018; Kashuba et al., 2016; Poljanec-Borić, Wertag, \& Carić, 2018), however, the previous studies on brand loyalty are not very common. The relationship between brand loyalty in health tourism is studied in rare cases. Therefore, this study formally documented the relationship between brand loyalty and health tourism. This study also considered the moderating role of brand trust which is also not well discussed in the field of health tourism. Brand trust is the important element of brand loyalty (Laroche, Habibi, Richard, \& Sankaranarayanan, 2012). Therefore, this study examined the relationship between $\mathrm{BG}$, brand experience, $\mathrm{BP}$, tourist brand trust and health tourism brand loyalty. Hence, the objective of this study is to examine the brand loyalty of health tourism.

\section{Literature Review}

Tourism industry is a famous industry worldwide because of its significant contribution to various other industries. It is evident by the previous studies that this industry has important contribution to economy (Kryukova, Kaurova, \& Joma, 2017). Most of the countries are generating high revenue from this industry which contribute to the economy. It is also important because this industry creating many employment opportunities to the general people. Increase in employment opportunities also effect positively on the economy. Therefore, due to the major contribution to economy, most of the nations are majorly focusing on the development and sustainable growth of tourism industry.

Tourism has many types and each tourism type has unique importance for the countries. Cultural tourism involves the visits of tourists to see the culture of various countries. Religious culture is based on the visits of other country people for the sake of religious events. The other tourism types include; environmental tourism, historical tourism, ethnic tourism, adventure tourism and health tourism. The current study is concerned with health tourism. Health tourism is one of the forms of tourism that contains of different patients traveling to various other countries to avail the services of medical treatment or any type of medical assistance. It includes all the services connected with tourism like transport, accommodation as well as hospitality. This tourism is based on the health industry. Better the health industry better will be health tourism (Pocock \& Phua, 2011).

There are different factors which effect on this industry which contribute to the brand loyalty in health tourism. First, BG has relationship with health tourism brand loyalty. Second, BP also has important link with brand tourism. Better the BP better will be the effect on brand loyalty. Third, the brand influence also has major effect on brand loyalty. The tourists having good experiment generally remain loyal to the brand. Along with these factors, brand trust also has major role. Therefore, BG, brand experience, BP and tourist brand trust are key to the brand loyalty. Figure 2 shows the relationship between BG, brand experience, BP, tourist brand trust and health tourism brand loyalty. 


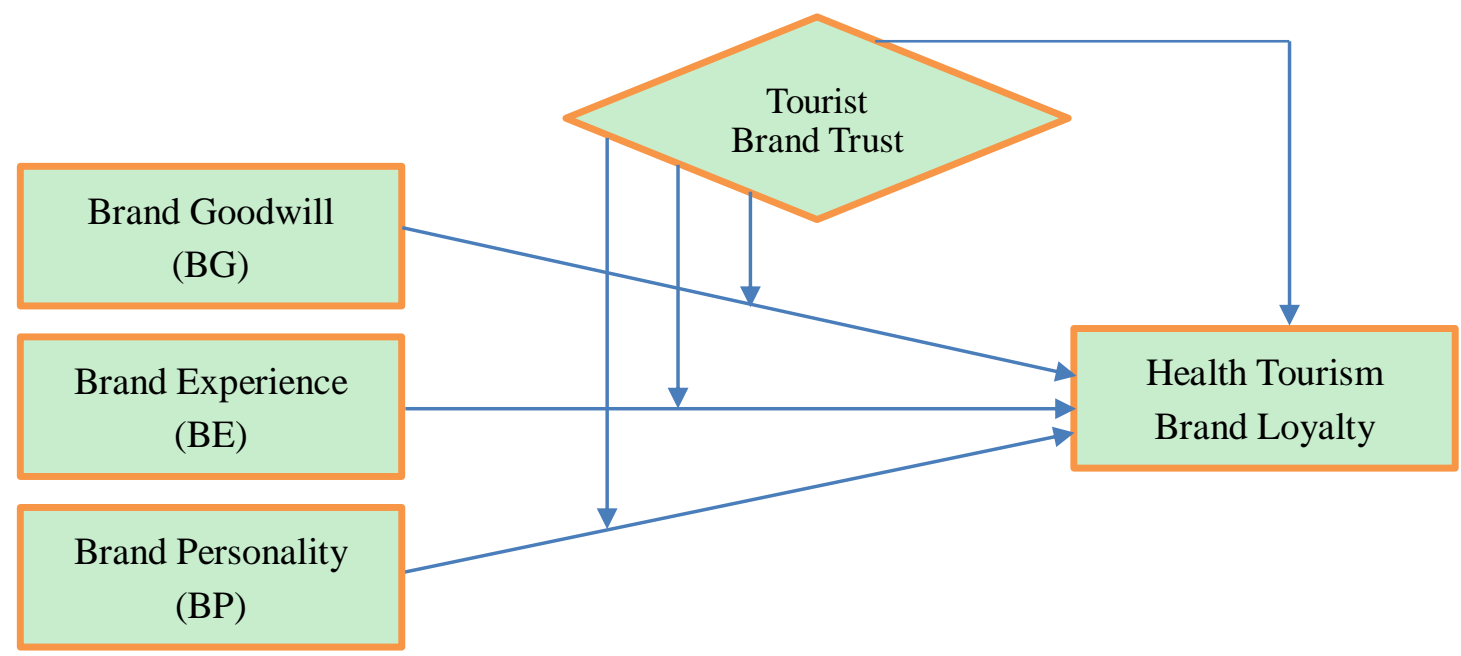

Figure 2. Theoretical framework of the study showing the relationship between BG, brand experience, BP, tourist brand trust and health tourism brand loyalty

\subsection{Brand Goodwill and Health Tourism Brand Loyalty}

Goodwill is one of the intangible properties as well as intangible asset that arises at the time when one organization buy another for some premium value. The worth of an organization brand name, solid customer, significant customer relations, important relationship with employee and any kind of patents or proprietary technology signify goodwill. The goodwill has significant relationship with the worth or any brand. It also have valuable relationship with loyalty (Danko et al., 2018; Nwanah Chizoba, Abomeh, \& Okafor Chika, 2019; Nzeribe, 2019; Razzaq, Maqbool, \& Hameed, 2019) which create brand worth. More the goodwill more will be the brand loyalty. Therefore, it has significant link with the tourism industry. Particularly, it has connection with the health industry. The health industry brands having high goodwill generally remain the intention of tourists. The countries having high brand loyalty of health sector, usually generate more revenue from health tourism. According to previous studies, goodwill always have important role in loyalty creation (Gonzalez, 2007). Kopalle and Assunção (2000) also described that goodwill has important relationship with brand. Therefore, in the sector of tourism, BG has positive effect to enhance health tourism brand loyalty as proposed in following hypothesis;

Hypothesis 1. BG has positive influence on health tourism brand loyalty.

\subsection{Brand Experience and Health Tourism Brand Loyalty}

$\mathrm{BE}$ is one of the important elements of experiential marketing that includes a holistic set of various conditions created by an organization to effect the feeling a customer has related to a particular product of the company or company name. $\mathrm{BE}$ is the experience of any individual after using the particular brand. BE is also important in health sector; therefore, it has connection with health tourism. Better BE has positive effect on health tourism which increases the brand loyalty. However, the tourist having not good brand experience, generally have negative effect on brand loyalty. Previous studies also highlighted a relationship between BE and brand loyalty (El Naggar \& Bendary, 2017; Rahmat \& Marso, 2020). These studies mentioned that BE is the major part of brand loyalty. In the health tourism sector, the brand loyalty is also significantly linked with brand loyalty which lead to the below hypothesis;

Hypothesis 2. BE has positive influence on health tourism brand loyalty.

\subsection{Brand Personality and Health Tourism Brand Loyalty}

Personality can be described as the characteristic sets of different behaviors, thoughts, and various emotional patterns which may include from biological as well as environmental elements. However, there is no commonly agreed description of personality. On the other hand, most of the theory's emphasis on motivation as well as psychological connections with one's environment. In case of BP, it can be explained as a BP is something to which the customer can relate; an actual brand upsurges its brand equity through a consistent set of different related traits that a definite consumer section enjoys. The BP has relationship with the loyalty of brand. Better personality of brand lead to the better brand loyalty. Literature proves that BP and brand loyalty have relationship (Chung \& Park, 2017; Zainudin et al., 2018). In the health tourism, BP also has important role to enhance brand loyalty. To enhance the health tourism 
brand loyalty, it is important to promote BP because a significant level of BP has the potential to influence health tourism brand loyalty positively. These augments are the basis of following hypothesis;

Hypothesis 3. BP has positive influence on health tourism brand loyalty.

\subsection{Tourist Brand Trust and Health Tourism Brand Loyalty}

Trust can be defined as a person's belief in the reliability, truth, or ability of someone or something. It is the trust of the customer on the company based on various product's reliability and durability. Fulfillment of customer expectations by the brand increases the level of trust, however, low fulfilment of the expectations of the brand lead to the low level of trust development. It has significant link with brand loyalty. As shown be previous studies that brand trust has relationship with brand loyalty (Mabkhot, Shaari, \& Salleh, 2017; Saragih et al., 2019). In case of health tourism, brand trust is also important. Tourist brand trust increases the health tourism brand loyalty. In the current study, brand trust is used as moderating variables which lead to the following hypotheses;

Hypothesis 4. Tourist brand trust has positive influence on health tourism brand loyalty.

Hypothesis 5. Tourist brand trust moderates the relationship between BG and health tourism brand loyalty.

Hypothesis 6. Tourist brand trust moderates the relationship between BE and health tourism brand loyalty.

Hypothesis 7. Tourist brand trust moderates the relationship between BP and health tourism brand loyalty.

\section{Research Methodology}

A quantitative research approach was used in this study to examine the relationship between BG, brand experience, $\mathrm{BP}$, tourist brand trust and health tourism brand loyalty. Therefore, five key variables were measured in this study by using quantitative research approach. BG was measured by examining the image of health tourism in the minds of tourists. For this purpose, various questions were asked related to the health tourism of Ranong city of Thailand. BE was measured by asking different questions related to the previous experience of various tourists related to the health services of Ranong. Moreover, BP was measured by asking the questions related to the brand equity and effectiveness of the brand. Questions were also asked related to the brand traits to measure the BP. Brand trust was measured by asking the questions related to the belief of tourists related to the brand reliability, truth, or ability. Reliability, truth, or ability was considered in terms of Ranong health services. As the better trust on health services has the ability to enhance brand loyalty. Finally, brand loyalty was measured by asking the questions that whether they would like to avail the health services of Ranong, Thailand, whether they recommend health services of Ranong to their relatives, family members and friends. All these variables were measured by using a Likert scale. As the Likert scale is important to get the opinion and views of people (Van Laerhoven, van der Zaag-Loonen, \& Derkx, 2004).

Population of the study is based on the tourists of Ranong city, Thailand. Only the tourists related to the health tourism were selected in this study. Questionnaires were used for data collection. The questionnaires were developed based on the measures revealed in above section. Total 300 questionnaires were distributed, and various tourists were asked to respond for the survey. For this purpose, the hospitals of Ranong were visited to find out tourists. Simple random sampling was used in this study because in this sampling everyone has the equal chance of being selected. From total 300 distributed questionnaires, 151 were returned and used for data analysis. Finally, Likert scale was divided in to two sections. The first section was based on the respondent's profile and second section was based on the research items related to the BG, brand experience, BP, tourist brand trust and health tourism brand loyalty.

\section{Data Analysis and Findings}

Data analysis of the study is started from data screening. Missing value in the data were removed, as the missing value can alter the results (Aydin \& ŞENOĞLU, 2018). All the missing values were fixed as shown in Table 1 that data has no missing value. Moreover, data mean, median and outlier is also presented in Table 1.

Table 1. Data statistics

\begin{tabular}{lccccccccc}
\hline & No. & Missing & Mean & Median & Min & Max & SD & Kurtosis & Skewness \\
\hline BG1 & 1 & 0 & 2.678 & 4 & 1 & 5 & 1.929 & -1.563 & -0.227 \\
BG2 & 2 & 0 & 3.497 & 4 & 1 & 5 & 0.967 & -0.393 & -0.128 \\
BG3 & 3 & 0 & 3.49 & 4 & 1 & 5 & 1.267 & -0.79 & -0.527 \\
BG4 & 4 & 0 & 3.43 & 4 & 1 & 5 & 0.357 & -1.001 & -0.427
\end{tabular}




\begin{tabular}{llllllllll} 
BE1 & 5 & 0 & 3.369 & 4 & 1 & 5 & 1.382 & -0.983 & -0.149 \\
BE2 & 6 & 0 & 2.409 & 3 & 1 & 5 & 0.948 & -1.393 & -0.189 \\
BE3 & 7 & 0 & 3.483 & 4 & 1 & 5 & 0.072 & -0.522 & -0.102 \\
BE4 & 8 & 0 & 3.456 & 4 & 1 & 5 & 1.256 & -0.793 & -0.486 \\
BP1 & 9 & 0 & 3.43 & 4 & 1 & 5 & 1.312 & -0.87 & -0.511 \\
BP2 & 10 & 0 & 2.57 & 4 & 1 & 5 & 0.853 & -0.237 & -0.122 \\
BP3 & 11 & 0 & 3.53 & 4 & 1 & 5 & 1.98 & -0.415 & -0.366 \\
BP4 & 12 & 0 & 3.356 & 4 & 1 & 5 & 1.391 & -1.028 & -0.492 \\
TBT1 & 13 & 0 & 3.584 & 4 & 1 & 5 & 0.844 & -1.154 & -0.101 \\
TBT2 & 14 & 0 & 3.523 & 4 & 1 & 5 & 1.98 & -0.427 & -0.347 \\
TBT3 & 15 & 0 & 2.557 & 4 & 1 & 5 & 1.089 & -0.095 & -0.683 \\
TBT4 & 16 & 0 & 3.584 & 4 & 1 & 5 & 1.118 & -0.215 & -0.193 \\
TBT5 & 17 & 0 & 3.403 & 4 & 1 & 5 & 0.146 & -0.502 & -0.568 \\
HTBL1 & 18 & 0 & 3.577 & 4 & 1 & 5 & 1.188 & -0.555 & -0.561 \\
HTBL2 & 19 & 0 & 2.651 & 4 & 1 & 5 & 1.123 & -0.268 & -0.627 \\
HTBL3 & 20 & 0 & 3.584 & 4 & 1 & 5 & 1.011 & 0.084 & -0.704 \\
HTBL4 & 21 & 0 & 3.779 & 4 & 1 & 5 & 0.289 & -0.417 & -0.131 \\
HTBL5 & 22 & 0 & 3.705 & 4 & 1 & 5 & 1.15 & -1.178 & -0.739 \\
HTBL6 & 23 & 0 & 2.792 & 4 & 1 & 5 & 1.322 & -0.687 & -0.736 \\
HTBL7 & 24 & 0 & 3.597 & 4 & 1 & 5 & 1.061 & -0.427 & -0.462 \\
\hline & & & & & & & & & \\
\hline
\end{tabular}

In Figure 3, PLS measurement model is given. It is carried out to check the factor loadings, reliability and validity. This is most recommended step by previous studies for factor loadings and to test the reliability and validity (Dahri, Hameed, Nawaz, Sami, \& Bux Shah, 2019; Hair Jr, Sarstedt, Hopkins, \& Kuppelwieser, 2014; Hair, Sarstedt, Pieper, \& Ringle, 2012; Olarewaju, 2019; Olowolaju, 2018). Figure 3 shows that BG is measured through four items. BE is measured through four items. BP is also measured through four items. All these variables have factor loadings above 0.5. Moreover, tourist brand trust is measured through five items and one item were deleted due to low factor loadings. Finally, health tourism brand loyalty was measured through seven items and all items have factor loadings above 0.5 . Factor loadings are given in Table 2.

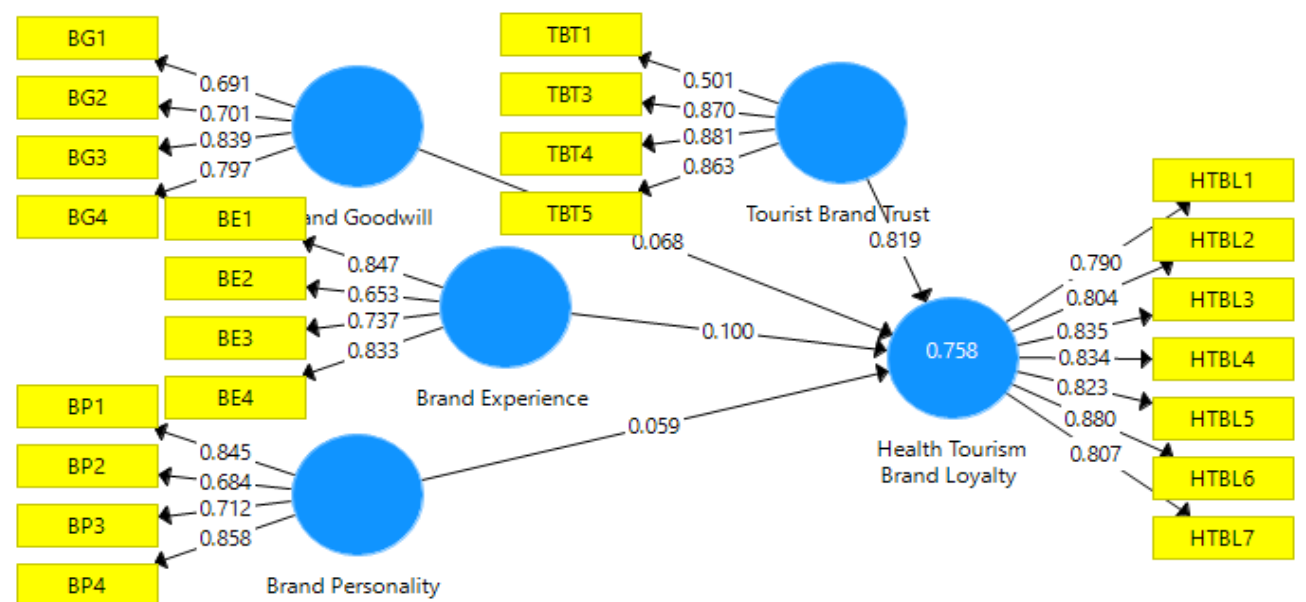

Figure 3. Measurement model 
Table 2. Factor loadings

\begin{tabular}{lccccc}
\hline & $\begin{array}{c}\text { Brand } \\
\text { Experience }\end{array}$ & BG & BP & $\begin{array}{c}\text { Health Tourism } \\
\text { Brand Loyalty }\end{array}$ & $\begin{array}{c}\text { Tourist Brand } \\
\text { Trust }\end{array}$ \\
\hline BE1 & 0.847 & & & & \\
BE2 & 0.653 & & & & \\
BE3 & 0.737 & & & & \\
BE4 & 0.833 & & & & \\
BG1 & & 0.691 & & & \\
BG2 & & 0.701 & & & \\
BG3 & & 0.839 & & & \\
BG4 & & 0.797 & & & \\
BP1 & & & 0.845 & & \\
BP2 & & & 0.684 & & \\
BP3 & & & 0.712 & & \\
BP4 & & & 0.858 & & 0.863 \\
HTBL1 & & & & 0.79 & \\
HTBL2 & & & & 0.804 & \\
HTBL3 & & & & 0.835 & \\
HTBL4 & & & & 0.834 & \\
HTBL5 & & & & 0.823 & \\
HTBL6 & & & & 0.807 & \\
HTBL7 & & & & & \\
TBT1 & & & & & \\
TBT3 & & & & & \\
TBT4 & & & & & \\
TBT5 & & & & & \\
\hline
\end{tabular}

Table 3 provided the composite reliability (CR) and average variance extracted (AVE). CR and AVE must be above 0.7 and 0.5, respectively (Hair, Hollingsworth, Randolph, \& Chong, 2017; Henseler \& Fassott, 2010). It is found that goodwill, brand experience, BP, tourist brand trust and health tourism brand loyalty have CR above 0.7. Moreover, AVE was used for convergent validity. All the variables; goodwill, brand experience, BP, tourist brand trust and health tourism brand loyalty have AVE above 0.5 which confirms the convergent validity. Discriminant validity is given in Table 4.

Table 3. Alpha, CR and AVE

\begin{tabular}{lcccc}
\hline & Alpha & rho_A & $\begin{array}{c}\text { Composite } \\
\text { Reliability }\end{array}$ & (AVE) \\
\hline BE & 0.777 & 0.807 & 0.853 & 0.595 \\
BG & 0.758 & 0.777 & 0.844 & 0.577 \\
BP & 0.783 & 0.813 & 0.859 & 0.606 \\
Health Tourism Brand Loyalty & 0.922 & 0.923 & 0.937 & 0.681 \\
Tourist Brand Trust & 0.795 & 0.852 & 0.868 & 0.632 \\
\hline
\end{tabular}


Table 4. Cross-loadings

\begin{tabular}{lccccc}
\hline & $\begin{array}{c}\text { Brand } \\
\text { Experience }\end{array}$ & BG & BP & $\begin{array}{c}\text { Health Tourism } \\
\text { Brand Loyalty }\end{array}$ & $\begin{array}{c}\text { Tourist Brand } \\
\text { Trust }\end{array}$ \\
\hline BE1 & 0.847 & 0.766 & 0.814 & 0.475 & 0.446 \\
BE2 & 0.653 & 0.621 & 0.641 & 0.244 & 0.34 \\
BE3 & 0.737 & 0.573 & 0.576 & 0.394 & 0.447 \\
BE4 & 0.833 & 0.778 & 0.697 & 0.467 & 0.42 \\
BG1 & 0.544 & 0.691 & 0.603 & 0.38 & 0.478 \\
BG2 & 0.614 & 0.701 & 0.644 & 0.253 & 0.344 \\
BG3 & 0.81 & 0.839 & 0.692 & 0.455 & 0.424 \\
BG4 & 0.711 & 0.797 & 0.776 & 0.398 & 0.348 \\
BP1 & 0.7 & 0.769 & 0.845 & 0.412 & 0.356 \\
BP2 & 0.564 & 0.572 & 0.684 & 0.343 & 0.444 \\
BP3 & 0.644 & 0.676 & 0.712 & 0.309 & 0.377 \\
BP4 & 0.814 & 0.753 & 0.858 & 0.49 & 0.444 \\
HTBL1 & 0.392 & 0.369 & 0.384 & 0.79 & 0.749 \\
HTBL2 & 0.512 & 0.49 & 0.495 & 0.804 & 0.746 \\
HTBL3 & 0.465 & 0.446 & 0.465 & 0.835 & 0.714 \\
HTBL4 & 0.468 & 0.429 & 0.427 & 0.834 & 0.704 \\
HTBL5 & 0.393 & 0.406 & 0.368 & 0.823 & 0.711 \\
HTBL6 & 0.425 & 0.413 & 0.408 & 0.88 & 0.743 \\
HTBL7 & 0.4 & 0.346 & 0.386 & 0.807 & 0.622 \\
TBT1 & 0.558 & 0.621 & 0.618 & 0.383 & 0.801 \\
TBT3 & 0.432 & 0.402 & 0.393 & 0.713 & 0.87 \\
TBT4 & 0.443 & 0.411 & 0.409 & 0.775 & 0.881 \\
TBT5 & 0.386 & 0.385 & 0.37 & 0.798 & 0.863 \\
\hline
\end{tabular}

Figure 4 shows the inner model or structural model of PLS with the help of PLS bootstrapping which is recommended by previous studies (Hair, Ringle, \& Sarstedt, 2013; Henseler, Ringle, \& Sinkovics, 2009; Omkar, 2020; Onogwu \& Ja afaru, 2020; Orfé, Gilbert, \& Honoré, 2019; Zahra, Hameed, Fiaz, \& Basheer, 2019). In this process, direct effect of BG, brand experience, BP and tourist brand trust were examined on health tourism brand loyalty. It is found that BG, brand experience, BP and tourist brand trust have significant positive effect on health tourism brand loyalty. Therefore hypothesis 1, 2, 3 and 4 are supported. Moderation effect is also given in Table 5 which shows the moderation effect is significant between BE and health tourism brand loyalty. Thus, hypothesis 6 is supported, however, hypothesis 5 and 7 are not supported. Moreover, Figure 5 shows that moderating effect strengthen the positive relationship between $\mathrm{BE}$ and health tourism brand loyalty. The r-square value is 0.758 as shown in Figure 3. It indicates that all the variables are expected to bring $75.8 \%$ change in health tourism brand loyalty which is substantial according to Chin (1998). 


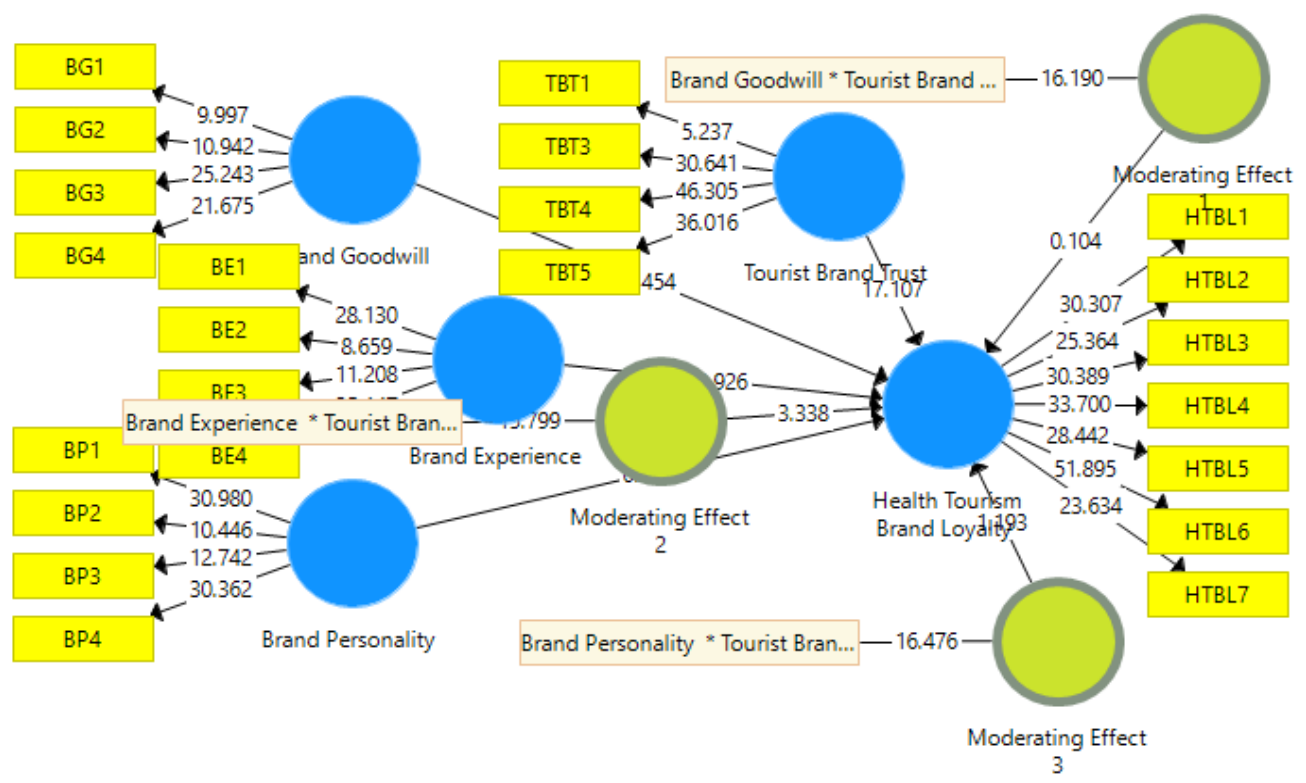

Figure 4. Structural model

Table 5. Direct effect results

\begin{tabular}{lccccc}
\hline & $(\mathbf{O})$ & $(\mathbf{M})$ & SD & Statistics & $\begin{array}{c}\text { P } \\
\text { Values }\end{array}$ \\
\hline BE-> Health Tourism Brand Loyalty & 0.105 & 0.094 & 0.036 & 2.926 & 0.003 \\
BG -> Health Tourism Brand Loyalty & 0.052 & -0.053 & 0.052 & 2.454 & 0.01 \\
BP -> Health Tourism Brand Loyalty & 0.042 & 0.054 & 0.018 & 2.367 & 0.015 \\
Moderating Effect 1 -> Health Tourism Brand Loyalty & 0.016 & 0.004 & 0.152 & 0.104 & 0.917 \\
Moderating Effect 2 -> Health Tourism Brand Loyalty & 0.18 & 0.155 & 0.054 & 3.338 & 0.002 \\
Moderating Effect 3 -> Health Tourism Brand Loyalty & 0.147 & 0.129 & 0.123 & 1.193 & 0.233 \\
Tourist Brand Trust -> Health Tourism Brand Loyalty & 0.816 & 0.816 & 0.048 & 17.107 & 0 \\
\hline
\end{tabular}

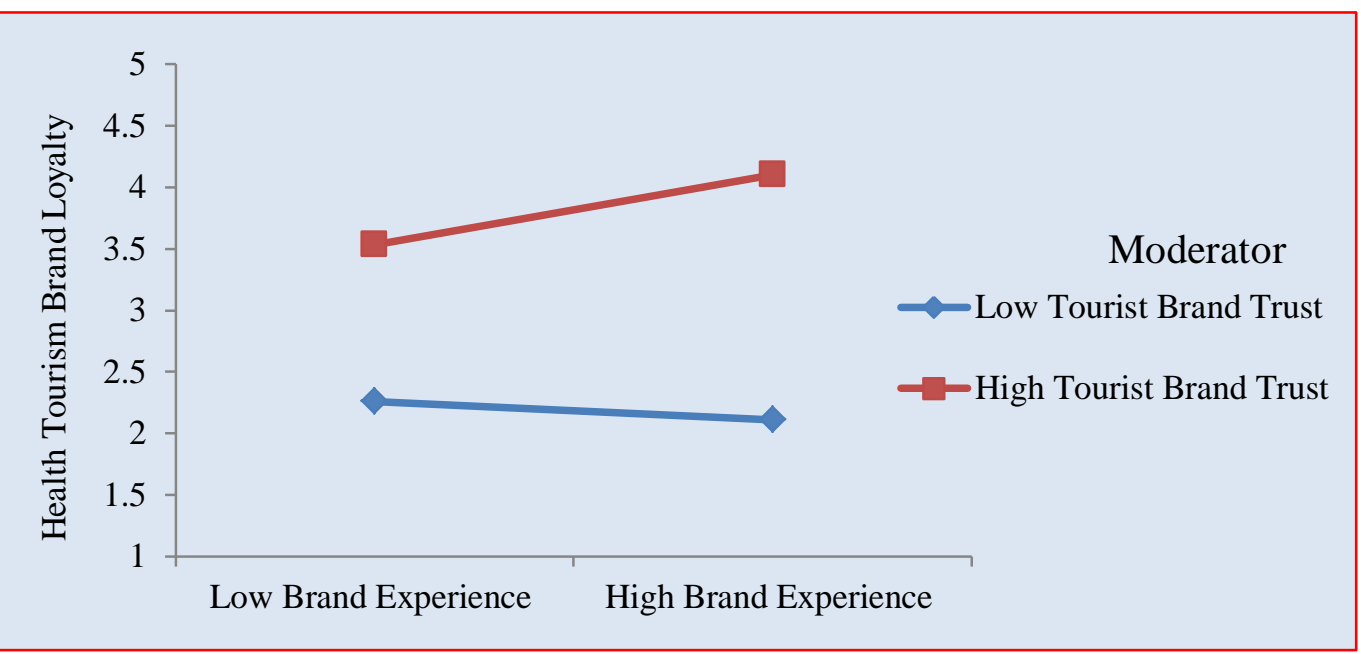

Figure 5. Moderation effect of tourist brand trust strengthen the positive relationship between BE and health tourism brand loyalty 


\section{Conclusion}

Objective of this study was to examine the brand loyalty of health tourism. For this purpose, the relationship between BG, brand experience, BP and tourist brand trust were examined. A questionnaires survey was carried out in this study to collect the data from the health tourists in Ranong city, Thailand. This study found four major determinants of health tourism brand loyalty.

Results of the study highlighted that BG; BE and BP have positive effect on brand loyalty. Increase in the goodwill of the health tourism has the ability to enhance brand loyalty. Positive increase in goodwill increase the brand loyalty of health tourism. Moreover, BE also has influential role in health tourism brand loyalty, as better BE creates the positive word of mouth and increase the brand loyalty. Along with BG and brand experience, BP also has important role in brand loyalty of health tourism. Positive change in BP has positive effect to increase brand loyalty of health tourism in Ranong, Thailand. Better BG, BE and BP have the potential to enhance brand loyalty of health tourism. Therefore, increase in BG, BE and BP increase the brand loyalty. Finally, the tourist brand trust also has positive effect to enhance brand loyalty. Trust has the potential to enhance the positive effect of brand determinants on health tourism brand loyalty. Therefore, health tourism brand loyalty has four determinants; BG, brand experience, BP and tourist brand trust. These four determinants have major contribution to enhance the health tourism brand loyalty in Ranong city, Thailand.

\subsection{Implications of the Study}

The current study has significant theoretical implications in the field of health tourism. As this study examined a valuable relationship between BG, brand experience, BP, tourist brand trust and health tourism brand loyalty. This is one of the valuable relationships in the field of health tourism which is not examined by the previous studies. The health tourism is examined in various previous investigations; however, it is not studied in relation to the $\mathrm{BG}, \mathrm{BE}$ and BP. In the other studies the tourism is discussed in relation to the brand loyalty, but it is not discussed in the health tourism. Especially, the health tourism of Ranong city is not discussed in the literature. This study also contributed to the literature because this study examined the role of goodwill on brand loyalty. As the BG is not discussed in relation to the brand loyalty. Furthermore, this study used brand tourist trust as moderating variable. This is the first study which examined moderating role of tourist trust in relation to the health tourism brand loyalty. Hence, this study has significant contribution theoretically. Nevertheless, practically, this study also has contribution to the practitioners. This study provides valuable insights for practitioners in a way to reveal the relationship between $\mathrm{BG}$, brand experience, BP and tourist brand trust with its effect on health tourism. This study is important for the tourism management of Ranong city to enhance brand loyalty. Because this study revealed that BG, brand experience, BP and tourist brand trust are the major determinants of health tourism brand loyalty. Ranong tourism management can enhance the health tourism by promoting BG, brand experience, BP and tourist brand trust.

\section{Limitations and Future Directions}

The current study has few limitations which could be the future directions. First, there are several determinants of brand loyalty in literature. Different studies examined different factors in relation to the brand loyalty and find out various determinants, therefore, the current study could not examine other determinants in health tourism. Hence, the future study should be carried out to examine the other determinants of brand loyalty in the field of health tourism. Second, the health services are always different from one country to another country, even from one city to another city. Therefore, along with the brand loyalty, there are various factors effecting on health tourism related to the health services. Definitely, the better health services promote health tourism, however, low quality health services decrease the health tourism potential. In this regard, this study did not consider the health services as one of the potential determinants of health tourism brand loyalty. Therefore, future research should be carried out to examine the effect of health services on health tourism brand loyalty. In other case, a comparison should be made between various other countries having good health services with Thailand, in this direction, the importance of health services for health tourism can be highlighted in a better way.

\section{References}

Aydin, D., \& Şenoğlu, B. (2018). Estimating the Missing Value in One-Way Anova Under Long-Tailed Symmetric Error Distributions. Sigma: Journal of Engineering \& Natural Sciences/Mühendislik ve Fen Bilimleri Dergisi, $36(2)$.

Chin, W. W. (1998). The partial least squares approach to structural equation modeling. Modern Methods for Business Research, 295(2), 295-336.

Chung, S., \& Park, J. (2017). The influence of brand personality and relative brand identification on brand loyalty in 
the European mobile phone market. Canadian Journal of Administrative Sciences/Revue Canadienne des Sciences de l'Administration, 34(1), 47-62.

Dahri, A. S., Hameed, W. U., Nawaz, M., Sami, A., \& Bux Shah, S. K. (2019). Nurses’ Job Satisfaction is Burned out by their Leaders and Stress. Journal of Managerial Sciences, 13(2).

Danko, T., Grishina, O., Kitova, O., Ivolgina, N., Solovyova, M., Seifullaeva, M., \& Sekerin, V. (2018). Management of Intangible Assets' Potential at Oil Companies: Market Positioning, Place and Role of Business Reputation--Goodwill of Companies. Journal of Applied Economic Sciences, 13(1).

de Almeida, I. C. S., \& Ribeiro, H. C. (2018). Health Tourism and Alternative Medicine: a Study on the Offer and Profile of Establishments nearby Two Hospitals in the City of Porto Alegre-Brazil. European Journal of Medicine and Natural Sciences, 2(1), 18-21.

El Naggar, R. A. A., \& Bendary, N. (2017). The Impact of Experience and Brand trust on Brand loyalty, while considering the mediating effect of brand Equity dimensions, an empirical study on mobile operator subscribers in Egypt. The Business \& Management Review, 9(2), 16-25.

F. Hair Jr, J., Sarstedt, M., Hopkins, L., \& G. Kuppelwieser, V. (2014). Partial least squares structural equation modeling (PLS-SEM) An emerging tool in business research. European Business Review, 26(2), 106-121.

Foroudi, P., Jin, Z., Gupta, S., Foroudi, M. M., \& Kitchen, P. J. (2018). Perceptional components of brand equity: Configuring the Symmetrical and Asymmetrical Paths to brand loyalty and brand purchase intention. Journal of Business Research, 89, 462-474.

Gonzalez, J. (2007). Trademark Goodwill, Brand Devaluation, and the Neo-Political Correctness of College Athletics: Did Marquette's Recent Identity Crisis Cost Them Thousands or Even Millions of Dollars in Brand Value. Sports Law. J., 14, 195.

Hair, J., Hollingsworth, C. L., Randolph, A. B., \& Chong, A. Y. L. (2017). An updated and expanded assessment of PLS-SEM in information systems research. Industrial Management \& Data Systems, 117(3), 442-458.

Hair, J. F., Ringle, C. M., \& Sarstedt, M. (2013). Partial least squares structural equation modeling: Rigorous applications, better results and higher acceptance.

Hair, J. F., Sarstedt, M., Pieper, T. M., \& Ringle, C. M. (2012). The use of partial least squares structural equation modeling in strategic management research: a review of past practices and recommendations for future applications. Long range planning, 45(5-6), 320-340.

Henseler, J., \& Fassott, G. (2010). Testing moderating effects in PLS path models: An illustration of available procedures. Handbook of partial least squares (pp. 713-735). Springer.

Henseler, J., Ringle, C. M., \& Sinkovics, R. R. (2009). The use of partial least squares path modeling in international marketing. New challenges to international marketing (pp. 277-319). Emerald Group Publishing Limited.

Iglesias, O., Markovic, S., \& Rialp, J. (2019). How does sensory brand experience influence brand equity? Considering the roles of customer satisfaction, customer affective commitment, and employee empathy. Journal of Business Research, 96, 343-354.

Jeong, Y., Kim, S.-K., \& Yu, J.-G. (2020). Sustaining Sporting Destinations through Improving Tourists' Mental and Physical Health in the Tourism Environment: The Case of Korea. International Journal of Environmental Research and Public Health, 17(1), 122.

Kashuba, V., Goncharova, N., \& Butenko, H. (2016). Effectiveness of health tourism application as the basis of health related recreational technology in primary school pupils' physical education. Pedagogics, psychology, medical-biological problems of physical training and sports, 20(2), 19-25.

Kopalle, P. K., \& Assunção, J. L. (2000). When (not) to indulge in 'puffery': The role of consumer expectations and brand goodwill in determining advertised and actual product quality. Managerial and Decision Economics, 21(6), 223-241.

Kryukova, E., Kaurova, O., \& Joma, S. (2017). The Impact of the Economy on Training of Specialists (In the Context of Tourism and Hospitality Industry of Russia and Latvia). Economic and Social Development: Book of Proceedings, 1021-1027.

Laroche, M., Habibi, M. R., Richard, M.-O., \& Sankaranarayanan, R. (2012). The effects of social media based brand communities on brand community markers, value creation practices, brand trust and brand loyalty. Computers in Human Behavior, 28(5), 1755-1767.

Mabkhot, H. A., Shaari, H., \& Salleh, S. M. (2017). The influence of brand image and brand personality on brand 
loyalty, mediating by brand trust: An empirical study. Jurnal Pengurusan (UKM Journal of Management), 50.

Nwanah Chizoba, P., Abomeh, O. S., \& Okafor Chika, M. (2019). impact of participatory decision making on organisational goal attainment. International Journal of Business, Economics and Management, 6(1), 1-15.

Nzeribe, A. (2019). Appointment of directors and performance of deposit money banks in sub Saharan Africa: Do we need more executive or non-executive directors?. Journal of Empirical Studies, 6(1), 1-18.

Olarewaju, F. O. (2019). Determinants of public sector corruption in Nigeria. International Journal of Public Policy and Administration Research, 6(1), 1-11.

Olowolaju, P. S. (2018). Effect of non-interest income on profitability of deposit money banks in Nigeria Journal of Banking and Financial Dynamics, 2(1), 1-8.

Omkar, D. (2020). Impact of digital marketing on online purchase intention: Mediation effect of customer relationship management. Journal of Asian Business Strategy, 10(1), 142-158.

Onogwu, E. E., \& Ja afaru, G. S. (2020). Influence of Innovation on the performance of small and medium-scale enterprises in Kogi State. Journal of Asian Business Strategy, 10(1), 122-132.

Orfé, C., Gilbert, N., \& Honoré, T. (2019). Effects of socio-economic conditions on the relationship between public and private investments in the cemac zone. Asian Journal of Economic Modelling, 7(1), 1-13.

Pocock, N. S., \& Phua, K. H. (2011). Medical tourism and policy implications for health systems: a conceptual framework from a comparative study of Thailand, Singapore and Malaysia. Globalization and Health, 7(1), 12.

Poljanec-Borić, S., Wertag, A., \& Carić, H. (2018). The Perception of Ecosystem Services in Public Sector Domains of Health, Tourism and Environment Protection in Croatia. Sociologija i prostor: časopis za istraživanje prostornoga i sociokulturnog razvoja, 56(2 (211)), 119-136.

Pranee, S., Boonying, J., \& Suchookorn, P. (2020). Community-Based Tourism Model of Otop Village Champion (OVC) A Case Study of Ban Ngao Community, Ranong Province. Paper presented at the International Academic Multidisciplinary Research Conference in Switzerland 2020.

Rahmat, R., \& Marso, M. (2020). Hubungan Brand Experience, Brand Image, Brand Satisfaction, Dan Brand Loyalty Dalam Pespektif Four-Stage Loyalty Model (Studi Terhadap Mahasiswa Pengguna Smartphone Di Tarakan). Jurnal Manajemen Pemasaran, 14(1), 17-24.

Razzaq, S., Maqbool, N., \& Hameed, W. U. (2019). Factors Effecting The Elasticity Of Micro Credit Demand In Southern Punjab, Pakistan. International Journal of Social Sciences and Economic Review, 1(2), 46-53.

Saragih, M. G., Surya, E. D., Rahayu, S., Harianto, H., Harahap, R., \& Widodo, S. (2019). Analysis Of Brand Experience And Brand Satisfaction With Brand Loyalty Through Brand Trust As A Variable Mediation. Paper presented at the Journal of International Conference Proceedings.

Van Laerhoven, H., van der Zaag-Loonen, H. J., \& Derkx, B. H. (2004). A comparison of Likert scale and visual analogue scales as response options in children's questionnaires. Acta paediatrica, 93(6), 830-835.

Wilkinson, P. F. (2020). Tourism, health, wellbeing and protected areas, edited by Iride Azara, Elina Michopoulou, Frederico Niccolini, B. Derrick Taff, and Alan Clarke, Wallingford, UK, CABI, 2018, p. 225. Taylor \& Francis.

Yang, S., Isa, S. M., Ramayah, T., \& Blanes, R. (2019). The Development of a Conceptual Framework on the Brand Personality, Self-congruity and Tourist Loyalty: The Moderator Role of Tourist Emotional Experience. Paper presented at the 9th Advances in Hospitality and Tourism Marketing and Management Conference Proceedings.

Zahra, M., Hameed, W. U., Fiaz, M., \& Basheer, M. F. (2019). Information Technology Capability a Tool to Expedite Higher Organizational Performance. UCP Management Review (UCPMR), 3(1), 94-112.

Zainudin, M. I. B., Ali, A.-A. E. B. R., Fadzil, A. S. A., Sarin, M. F., Zaki, N. A. S. B. A., Othman, A. K., \& Hassan, F. H. (2018). Halal Brand Personality and Brand Loyalty among Millenials Modest Fashion Consumers in Malaysia: A Conceptual Paper.

\section{Copyrights}

Copyright for this article is retained by the author(s), with first publication rights granted to the journal.

This is an open-access article distributed under the terms and conditions of the Creative Commons Attribution license (http://creativecommons.org/licenses/by/4.0/). 